\title{
KNOWLEDGE OF THE IMPORTANCE OF IODINE IN NUTRITION AMONG ADULTS IN LATVIA
}

\author{
Elīna Ciekure ${ }^{\#}$ and Inese Siksna \\ Institute of Food Safety, Animal Health and Environment BIOR, 3 Lejupes Street, Rīga, LV-1076, LATVIA \\ \# Corresponding author, elina.ciekure@bior.Iv
}

Communicated by Aivars Bērziṇš

\begin{abstract}
The Food and Agriculture Organisation of the United Nations (FAO) states that it is essential for people to understand what constitutes a healthy diet and to know how to use their resources in the most effective way. lodine is an essential nutrient for mammals, required as a mandatory structural and functional element of thyroid hormones. Previous studies in Latvia highlighted a tendency of reduced level of iodine for newborns, school-age children and pregnant women. No studies in the general adult population had been conducted yet. The aim of the study was to evaluate the level of knowledge regarding the role of iodine in nutrition in the adult population of Latvia. In total 199 adults participated in the survey. Data on the knowledge about the occurrence of iodine in nature and foodstuffs, the role of iodine in nutrition, and its deficiency were obtained. Results of the survey showed that only $4.5 \%$ of respondents used iodised salt daily in the diet. One-fourth knew that iodine is widely found in the environment and more than one-third knew all of the main functions of iodine in the human body. Salt and sea food were mentioned as the most common iodine sources. While iodised salt is used rarely, public awareness about the role of iodine is good and potential iodine deficiency in Latvia is likely due to unbalanced diet rather than lack of knowledge.
\end{abstract}

Key words: iodine, iodine deficiency, public awareness, nutrition.

\section{INTRODUCTION}

The Food and Agriculture Organisation of the United Nations (FAO) highlights that even if people have physical and economic access to food, it is not sufficient to ensure that they are food secure and well nourished. "It is essential that people understand what constitutes a healthy diet; in particular, what nutrition-related health issues affect their communities and how to address these through food-based approaches, and know how to make the best use of their resources. They should also have positive attitudes towards nutrition, diet, foods and closely related hygiene and health issues to be able to perform optimal dietary and feeding practices that ensure their nutritional wellbeing and that of their families" (Macías and Glasauer, 2014).

Iodine deficiency is one of the most common nutritional deficiencies. It is estimated that worldwide almost 2 billion people are at risk of iodine deficiency. Iodine deficiency is severe in regions of Africa, Southeast Asia, and Latin America; in Europe mild and average iodine deficiency is common. Iodine is an important micronutrient during a humans' lifespan. It affects functions of the thyroid gland. It is necessary for human cognitive functions and IQ, but it is more important during pregnancy and lactation, and for de- velopment of foetus and newborns (Anonymous, 2008; Tulchinsky, 2010; Anonymous, 2014).

Previous studies in Latvia indicated iodine deficiency in vulnerable population groups. Data published in 2015 showed deficiency for pregnant women in Latvia (Konrade et al., 2015). Mild iodine deficiency among schoolchildren was found in 2000 and again in 2010/2011 when results from urinary iodine concentration (UIC) data showed that $31.6 \%$ school-aged children had mild, $11.9 \%$ - moderate and 2.8\% - severe iodine deficiency (Selga et al., 2000; Konrade et al., 2014). Seasonal changes in the iodine level for school-aged children were observed (Konrade et al., 2012). The national neonatal thyrotropin (TSH) screening data for 2000-2002 showed that Latvia is iodine deficient, putting each new generation at risk of preventable brain damage (Gyurjyan et al., 2006).

At present there are no studies in Latvia on iodine status in the general adult population and there is no data about knowledge of the importance of iodine in any population group.

Studies that evaluate people's nutrition-related knowledge, attitudes and practices have been used for two main purposes: (1) to collect key information during a situation analysis, which can then be used in the design of nutrition inter- 
ventions and (2) to evaluate nutrition education interventions (Macías and Glasauer, 2014).

The aim of the study was to evaluate the level of knowledge on the role of iodine in nutrition in the adult population of Latvia.

\section{MATERIALS AND METHODS}

A cross-sectional study was carried out in Latvia in the adult population aged 19-64. To obtain a nationally representative random sample of healthy Latvian adults, a two stages stratified random sampling procedure was performed in a subpopulation. In the first stage of sampling, family doctors practices were stratified by region (Rīga District; Kurzeme; Vidzeme; Zemgale; Latgale) and settlement (Rìga city; another major city; another city or town; rural area). The sampling frame covered the entire survey population, as each resident of Latvia is required to register with a family doctor. In the second stage, the sampling frame consisted of all patients aged between 19 and 64 years and registered with the selected family doctor, stratified by sex and age group (19-25; 36-50; 51-64). Family doctors selected individuals based on a specific selection procedure prescribed by the researchers, and contacted selected individuals to inform them about the survey and to receive their consent to participate in the survey. Exclusion criteria were pregnancy and an unsigned consent form. After the family doctor approved that an individual had agreed to participate, trained personnel performed the survey. Data on eating habits and socio-demographic status were obtained. Questions about salt usage and questions regarding iodine occurrence in the environment, iodine functions in human body and about possible iodine deficiency in Latvia were asked. Respondents were asked to choose and mark answers in the questionnaire that they thought were correct to the given questions. There was also the option of choosing that were they were not sure about the given answers.

Before the national food consumption survey, questions related to iodine importance and occurrence were piloted during salt consumption pilot study $(n=30)$. The sampling method for the pilot project were the same as described above, using a two-stage stratified random sampling procedure and contacting potential respondents through family doctors. Based on results of the pilot project, the questionnaire was updated and the survey to assess iodine knowledge was performed as part of the national food consumption survey $(\mathrm{n}=169)$.

Approval of this study was received from the Ethics Committee of the Institute of Food Safety, Animal Health and Environment, "BIOR". All respondents were informed that they were not obligated to answer all questions, their participation is voluntary, and that all personal information would be confidential.

Statistical analyses were conducted using the IBM Statistical Package for Social Sciences (SPSS). Descriptive analysis was done to analyse frequencies of answers chosen by respondents. The effect of socio-demographic factors on knowledge was tested by bivariate correlation analysis; significance of correlations was assessed at the levels of 0.05 and 0.01 (2-tailed). Analysis of variance (ANOVA) and post-hoc analysis (Tukey's range test) were used to analyse the differences among groups.

\section{RESULTS}

In total, combining completed questionnaires from the pilot study and consumption study, answers to questions regarding iodine were received from 199 respondents (111 women and 88 men). $60 \%$ of respondents were from Rìga District, $16 \%$ from Latgale, 9\% - from Kurzeme, 8\% - from Zemgale and $7 \%$ from Vidzeme.

Almost half of respondents (48\%) had secondary school education; $44 \%$ of respondents had higher education (master or bachelor's degree, or higher education received during the Soviet period); $8 \%$ of respondents had primary school level education and one respondent did not answer the question about education. No significant relationship between age groups and the level of education was found.

Level of monthly income per one family member was divided in six categories: very low income (1.00 to 70.00 EUR); low (70.01 to 150.00 EUR); good (150.01 to 220.00 EUR); very good (220.01 to 350.00 EUR); high (350.01 to 500.00 EUR), and very high (> 500.01 EUR). Twenty-eight per cent of the respondents reported that their income was very good. A small proportion (4\%) of respondents had a very low income and also a small proportion $(10 \%)$ had a very high income; $13 \%$ of respondents did not want to report their income. There was no statistically significant difference $(p<0.05)$ in the level of income among regions; there was a significant weak positive correlation at the 0.05 level between level of income and level of education $(\mathrm{r}=$ -0.166 ). In the group with the lowest income, $65 \%$ of respondents had secondary school education and the highest level of education was the $1^{\text {st }}$ level of higher education (bachelor degree or college education).

Iodine in the environment. A multiple choice question about the occurrence of iodine in environment was given to determine if respondents knew the basic facts about iodine. Most respondents $(31 \%)$ knew that iodine is found in iodised salt, and $25 \%$ knew that iodine can be found in ocean and sea water and sediments (Fig. 1). Overall $61 \%$ of respondents who answered to question chose 1 to 2 correct sources of iodine; $11 \%$ chose 3 to 4 correct sources and $24 \%$ considered that iodine can be found in all of the given objects - soil and rocks, air, iodised salt, ocean, sea and sediments, and tap (drinking) water. Only $4 \%$ of respondents answered incorrectly by selecting the answer that iodine cannot be found in nature and it is synthesised in laboratory conditions, or stated that they did not know. There were six respondents who did not answer the question.

To obtain additional information about knowledge of respondents in the salt pilot project, they were asked if they 


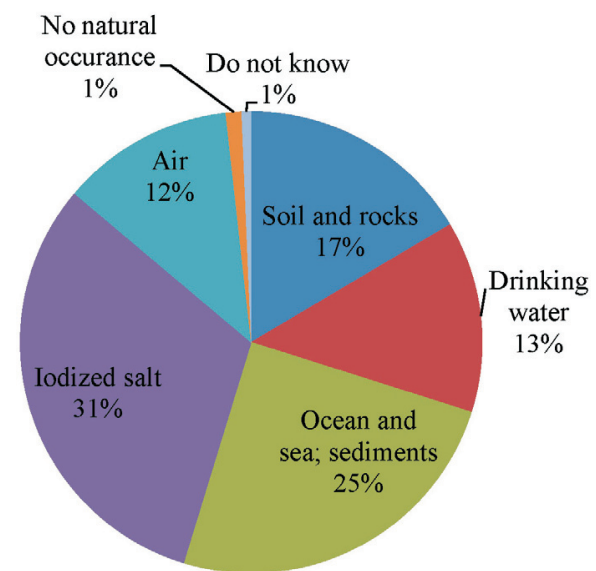

Fig. 1. Frequency of answers to the question "Do you know where iodine can be found in the environment?".

knew the role of iodine in human nutrition, and the majority (78.6\%) chose correctly that iodine is microelement (trace element), $10.7 \%$ said that they did not know the role of iodine in the human diet and $10.7 \%$ replied that it is mineral and did not specify what type of mineral.

Knowledge about iodine in environment had significant weak negative correlation at the 0.05 level $(r=-0.141)$ with knowledge about iodine functions and with level of education of respondent $(\mathrm{r}=-0.142)$. Almost all respondents with a master's degree or higher education received during the Soviet period $(96 \%$ and $100 \%)$ chose the right answers to the question about iodine occurrence in environment. However, respondents with a lower level of education had a tendency to answer that they did not know the answer to the question (secondary school level - 2\%; the first level of higher education $-2 \%$ ) or they thought that iodine in synthesised in laboratory conditions (secondary school level $3 \%$; the first level of higher education $-2 \%$ ).

Iodine functions. The most chosen answer (32\% of all given answers) to the multiple choice question about importance of iodine in the human body was "iodine is important during the lifetime for normal functioning of the thyroid gland, brain activity and intellect". Answers regarding the iodine importance in thyroid gland functions were often chosen, and the second most selected answer was (25\% of all given answers) that iodine deficiency can cause enlarged thyroid gland - goitre. Importance of iodine for the foetus and newborns was recognised also, and received a proportion of $24 \%$ of all given answers.

Overall, $37 \%$ of respondents correctly marked that all given answers are functions of iodine in human body; $28 \%$ knew one or two functions; $26 \%$ of respondents had heard that iodine is important for functioning of body, but they did not know its functions. Only $9 \%$ of respondents thought that the human body does not need iodine for its functions and $1 \%$ of respondents considered iodine to be harmful (true in the case of radioactive isotopes of iodine). Two respondents did not give any answers to this question.
Respondents from the pilot study $(\mathrm{n}=30)$ additionally were asked if severe iodine deficiency can cause cretinism, to which only $33 \%$ answered that this was true.

There was a significant weak positive correlation at the 0.01 level between knowledge of iodine functions in the human body and respondent gender $(r=0.243)$. All three given functions of iodine were known by $43 \%$ of women and $28 \%$ of men; $41 \%$ of male respondents and only $14 \%$ of female responded that they did not know any functions of iodine. More men (12\%) than women $(6 \%)$ thought that iodine did not have any special functions in the organism. There was a significant correlation at the 0.01 level among chosen answers about iodine functions and gender. 54\% female knew that iodine is important for the foetus and newborns, while only $30 \%$ men indicated this as a iodine functions $(r=$ $-0.238)$. The answer about iodine importance for thyroid functions, brain activity and intellect was correctly chosen by $71 \%$ of female and $43 \%$ of men $(r=-0.284)$. An enlarged thyroid gland as consequence of iodine deficiency was marked by $57 \%$ female and $31 \%$ of men $(r=-0.253)$.

There was a significant weak negative correlation at the 0.01 level among age groups and knowledge about iodine functions in the body $(\mathrm{r}=-0.253)$ and a significant difference $(p<0.05)$ among age groups $(p=0.002)$ (Fig. 2). There were statistically significant differences $(\mathrm{p}<0.05)$ among age groups in choices of what they thought $/ \mathrm{knew}$ were iodine functions in organism. The oldest group more often $(57 \%)$ than middle age respondents $(36 \%)$ marked that iodine is important for the foetus and newborns ( $p=$ 0.037). Less than one half $(48 \%)$ of respondents from group with ages 19-35 years thought that iodine is important for the thyroid gland, brain activity and intellect, however, $71 \%$ of respondents with age 51-64 years knew this function of iodine $(p=0.024)$. There was a significant difference $(p<$ $0.05 ; p=0.024$ ) between the youngest and the oldest age groups regarding knowledge on the relationship between iodine deficiency and an enlarged thyroid gland, which was acknowledged by $60 \%$ of the oldest respondents and only $37 \%$ of the youngest respondents. There was a significant difference $(p<0.05)$ in the proportion of people who do not know functions of iodine between age groups 36-50 (35\%) and 51-64 $(14 \%)(p=0.019)$. Significantly more $(p<0.05$;

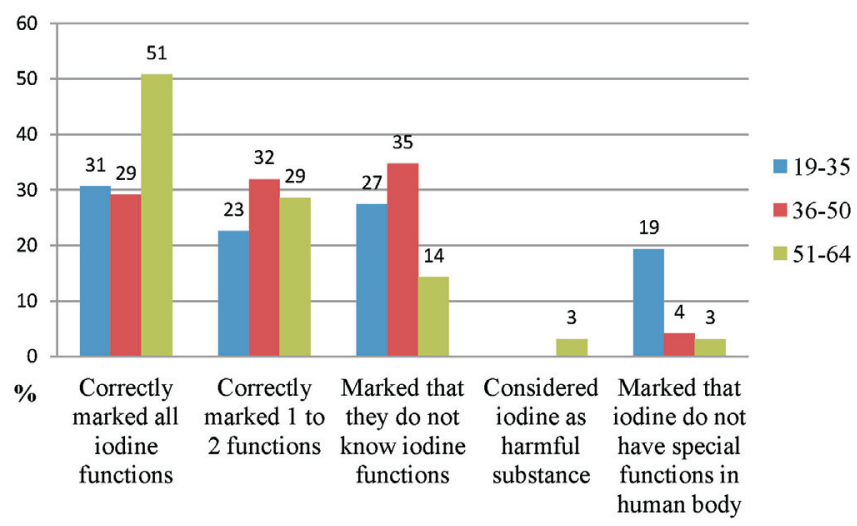

Fig. 2. Answers about iodine functions in the human body depending on respondent age. 
$p=0.004$, and $p=0.003$ ) young respondents answered that the human organism does not need iodine for its functions (19\%), $4 \%$ in the middle age group, and $3 \%$ in the oldest group chose this answer.

There was a significant weak positive correlation (at the 0.05 level) between iodised salt usage and knowledge of iodine functions $(r=-0.175)$. Iodised salt was exclusively used by $4.5 \%$ respondents, but exclusively and time by time iodised salt was used by $7 \%$ of women and $13 \%$ of men. Only $5 \%$ of respondents who exclusively and sometimes use iodised salt said that they did not know the functions of iodine, while $30 \%$ of respondents who do not use iodised salt did not know its functions (Fig. 2).

There was significant weak positive correlation $(p<0.05)$ among the level of education and knowledge of iodine functions $(\mathrm{r}=0.150) ; 85 \%$ of respondents with a master's or similar level of education; $80 \%$ of respondents with higher education received during the Soviet period; $64 \%$ with $1^{\text {st }}$ level higher education; $60 \%$ with secondary school education, and $44 \%$ of respondents with primary school education could name one to all functions of iodine.

Iodine deficiency. Almost half of the respondents (48\%) had heard about possible iodine deficiency in Latvia, and the other half (48\%) had not. Few respondents $(4 \%)$ thought that there was no iodine deficiency in the Latvian population. The age of respondents had a significant weak negative correlation $(p<0.01)$ with the fact that respondents had never heard about iodine deficiency in Latvia $(r=-0.253)$ and a significant positive negative correlation with respondents' knowledge about iodine deficiency $(r=0.208) .65 \%$ of respondents in the age group of 19-35 years had never heard about iodine deficiency in Latvia and only $32 \%$ had heard about it or knew something about it; in the age group of 36-50 years, $47 \%$ had never heard of this problem and $48 \%$ had heard of it; in the age group of 51-64 years $63 \%$ had heard about iodine deficiency and only $33 \%$ had never heard about it.

The opinion about iodine deficiency had a significant weak negative correlation $(p<0.01 ; \mathrm{r}=-0.472)$ with knowledge about iodine functions in organism. More than a half $(53 \%)$ of respondents who had heard about possible iodine deficiency in Latvia marked all functions of iodine. Most (39\%) of the respondents who had never heard about iodine deficiency answered that they knew that iodine is important but they did not know its functions (Table 1). Respondents who had heard about iodine deficiency most often (82\%) knew that iodine is important for the thyroid gland, brain activity and intellect.

Iodine dietary sources. Respondents were given a list of products which may or may not contain iodine and they had to mark products that they considered to be iodine dietary sources. Marine products were the most frequent answer (44\% of all given answers) to the question about iodine dietary sources, and iodised salt was the second most often chosen (37\% of all given answers). Milk and milk products
Table 1

ANSWERS TO QUESTIONS ABOUT POTENTIAL IODINE DEFICIENCY IN LATVIA AND KNOWLEDGE ABOUT IODINE FUNCTIONS

\begin{tabular}{|c|c|c|c|}
\hline \multicolumn{2}{|c|}{ Questions } & \multirow{2}{*}{$\begin{array}{c}\begin{array}{c}\text { Number of } \\
\text { answers }\end{array} \\
18\end{array}$} & \multirow{2}{*}{\begin{tabular}{|c}
$\begin{array}{c}\text { Percent of } \\
\text { valid } \\
\text { answers }\end{array}$ \\
19.1
\end{tabular}} \\
\hline \multirow{6}{*}{$\begin{array}{l}\text { Respondent had never } \\
\text { heard about possible } \\
\text { iodine deficiency in } \\
\text { Latvia }\end{array}$} & $\begin{array}{l}\text { Correctly marked all } \\
\text { iodine functions }\end{array}$ & & \\
\hline & $\begin{array}{l}\text { Correctly marked } 1 \text { to } 2 \\
\text { functions }\end{array}$ & 21 & 22.3 \\
\hline & $\begin{array}{l}\text { Marked that they do not } \\
\text { know iodine functions }\end{array}$ & 37 & 39.4 \\
\hline & $\begin{array}{l}\text { Considered iodine as } \\
\text { harmful substance }\end{array}$ & 1 & 1.1 \\
\hline & $\begin{array}{l}\text { Marked that iodine do } \\
\text { not have special } \\
\text { functions in human } \\
\text { body }\end{array}$ & 17 & 18.1 \\
\hline & Total & 94 & 100.0 \\
\hline \multirow{5}{*}{$\begin{array}{l}\text { Respondent had never } \\
\text { heard about possible } \\
\text { iodine deficiency in } \\
\text { Latvia }\end{array}$} & $\begin{array}{l}\text { Correctly marked all } \\
\text { iodine functions }\end{array}$ & 50 & 53.2 \\
\hline & $\begin{array}{l}\text { Correctly marked } 1 \text { to } 2 \\
\text { functions }\end{array}$ & 31 & 33.0 \\
\hline & $\begin{array}{l}\text { Marked that they do not } \\
\text { know iodine functions }\end{array}$ & 12 & 12.8 \\
\hline & $\begin{array}{l}\text { Considered iodine as a } \\
\text { harmful substance }\end{array}$ & 1 & 1.1 \\
\hline & Total & 94 & 100.0 \\
\hline \multirow{4}{*}{$\begin{array}{l}\text { Respondent thought } \\
\text { that there is no iodine } \\
\text { deficiency in Latvia }\end{array}$} & $\begin{array}{l}\text { Correctly marked all } \\
\text { iodine functions }\end{array}$ & 4 & 50.0 \\
\hline & $\begin{array}{l}\text { Correctly marked } 1 \text { to } 2 \\
\text { functions }\end{array}$ & 2 & 25.0 \\
\hline & $\begin{array}{l}\text { Marked that they do not } \\
\text { know iodine functions }\end{array}$ & 2 & 25.0 \\
\hline & Total & 8 & 100.0 \\
\hline
\end{tabular}

were chosen only by $2 \%$; one respondent indicated that sugar could be source of iodine, but no respondents thought that bread and pasta could be sources of iodine (Fig. 3). Respondents usually $(81 \%)$ correctly chose one or two products that can be iodine sources.

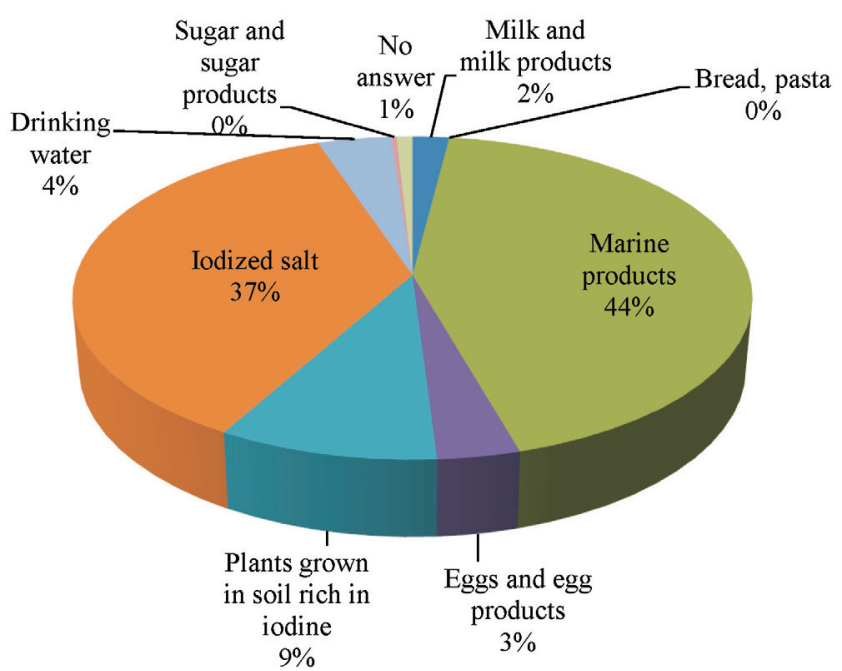

Fig. 3. Frequency of answers to the question "Can you name iodine dietary sources?". 
Additionally, pilot study respondents $(n=30)$ were asked to express their opinion about food product fortification with iodine. $30 \%$ of the respondents said that all salt on the market has to be fortified with iodine and $30 \%$ said that there was no need for additional product fortification, as the level of fortification in Latvia is suitable. $17 \%$ of respondents thought that all salt used in food production had to be iodised and that there was a need for additional product iodisation. The same proportion of respondents $(17 \%)$ had the opposite opinion - food product fortification with iodine was not needed. $7 \%$ of respondents said that additional fortification is needed only for special products for pregnant women and newborns.

There was a significant negative correlation $(p<0.01$ level; $r=-0.220$ ) between gender and choice of marine products as an iodine source $-85 \%$ of female and $66 \%$ male respondents marked them as an important iodine source. Iodised salt as a source of iodine was chosen by more than half of respondents - $64 \%$ of female and $65 \%$ of male respondents.

There was a significant weak positive correlation $(p<0.05)$ between dietary sources of iodine and place of residency of the respondent $(\mathrm{r}=0.144)$. Among regions respondents from Vidzeme (29\%) and Latgale (27\%) marked that most products (3-5) given in the list were iodine sources. There were statistically significant differences $(p<0.05)$ among choices of products as iodine sources among regions. Choice of milk and milk products as iodine sources significantly differed among regions $(p=0.004)$. Marine products were significantly $(p=0.041)$ more often considered as iodine sources in Kurzeme (94\% of respondents) than in Latgale (59\%); however, iodised salt as an iodine source was significantly less mentioned in Kurzeme (39\%) than in Latgale $(81 \%)(p=0.024)$ (Fig. 4).

\section{DISCUSSION}

Knowledge about the role of iodine in the human body is important not only for vulnerable groups, such as women in childbearing age, pregnant women, and school-age children, but also for the general population, as the community and specifically family members can impact knowledge and intake of iodine of vulnerable group members. A high level of public awareness helps to implement policy regarding pre-

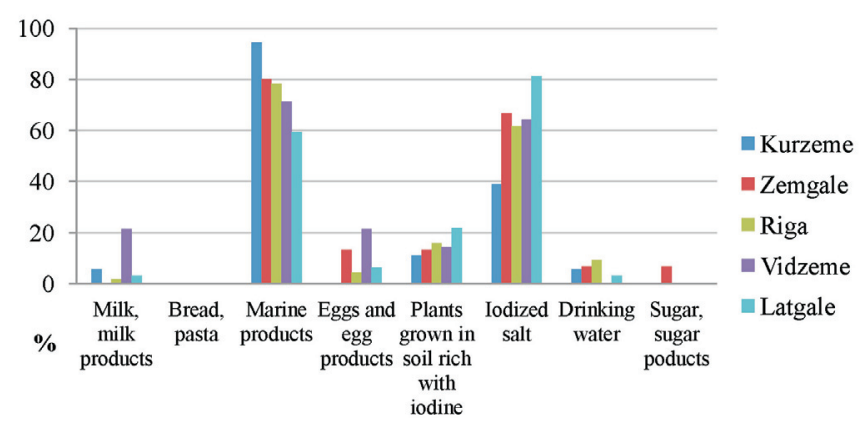

Fig. 4. The most popular answer marked in question regarding to iodine sources by regions. venting iodine deficiency. The present study helps to understand what type of public actions need to be implemented to raise public awareness or maintain it at a sufficient level. Assessment of knowledge about iodine is conducted mostly in regions were iodine deficiency is more severe (Jooste et al., 2005; Girma et al., 2012; Khan et al., 2012) or for vulnerable groups like pregnant women (Charlton et al., 2012; O'Kane et al., 2015). The main findings of the studies were that even for vulnerable groups the level of awareness was low and that the level of awareness increased with the level of education and socio-economic situation of respondents.

While correlations found in the study performed in Latvia among different factors and level of knowledge were weak, some tendencies could be seen. Knowledge was measured by the proportions of correct choices of answers for the given questions, based on descriptions about iodine in the literature. The level of knowledge was affected by respondent level of education and in some cases by age and gender; in this regard it must be noted that there was no statistically significant difference in level of education between genders. In the survey, knowledge of respondents did not differ among groups with different economic situation.

Good results was obtained in the question about iodine sources in the environment. Almost all respondents (96\%) could name at least one source of iodine in the environment. Answers about sources of iodine included iodised salt, which does not naturally occur, but it was not wrong to claim that it is an iodine source; $72 \%$ of respondents included it in their answers. More than a half of the respondents could name at least one function of iodine in the human organism and in total $91 \%$ of respondents knew or at least have heard that iodine has specific functions in the human body. Women could better name the functions of iodine, perhaps because iodine is important during pregnancy and for newborns. Women that have children are informed by the family doctor or informative materials about specific nutrition requirements, including increased need for iodine. Almost half of the respondents had at least one child in the family. It was observed that knowledge about iodine functions in the human body increased with age. In general, iodine was considered to be more associated with the thyroid gland and its functioning.

Results showed a tendency that knowledge could affect nutritional choices. Respondents who used iodised salt knew all functions of iodine. Based on this it could be concluded that easy understandable, scientific information about iodine and other nutrients could be useful for young people to raise their awareness and through that to improve their eating habits.

Knowledge of almost a half of respondents about iodine deficiency in Latvia indicates that the public is interested in questions related to health and nutrition. Respondents correctly marked that marine products and iodised salt are food products rich in iodine and are good iodine sources in nutrition. However, consumption of marine products, fish and fish products is low in Latvia (Joffe et al., 2009). Milk and 
milk products were mentioned rarely as an iodine source, while in the literature it is mentioned as one of main sources due to its large consumption (Zimmermann et al., 2001; Anonymous, 2014). Regional differences in choices of the main iodine food source might be explained by the geographical location of regions. Kurzeme is located near the Baltic Sea and residents of Kurzeme have strong fishing traditions, which might be why respondents from that region knew more about the positive nutritional value of fish, marine products or choose it because it was a well-known product for them.

There was a tendency that if a respondent chose correct answers to one question, then he or she would also chose correct answers to other questions.

\section{CONCLUSIONS}

While iodised salt was used rarely, public awareness about the role of iodine was good and the choice not to use iodised salt could be based on personal opinion/wish and not on lack of knowledge.

Reasons of possible iodine deficiency in Latvia could be unbalanced diet or small amount of iodine in food products, but to a lesser extent due to lack of knowledge about the importance of iodine.

A survey on assessing level of knowledge of iodine importance of respondents from vulnerable groups would be useful for action to eliminate iodine deficiency.

\section{ACKNOWLEDGEMENTS}

We appreciate the help of all family doctors involved, respondents who spent their time on the survey and specially trained interviewers. Special acknowledgement is given to the Institute of Food Safety, Animal Health and Environment, BIOR.

\section{REFERENCES}

Anonymous (2008). Sustainable Elimination of Iodine Deficiency. UNICEF. 43 pp.

Anonymous (EFSA) (2014). Scientific opinion on dietary reference values for iodine. EFSA J., 12 (5), 3660.

Received 10 October 2016

Acceted in the final form 29 November 2017
Charlton, K., Yeatman, H., Lucas, C., Axford, S., Gemming, L., Houweling, F., Goodfellow, A., Ma, G. (2012). Poor knowledge and practices related to iodine mutrition during pregnancy and lactation in Australian women: Preand post-iodine fortification. Nutrients, 4, 1317-1327.

Girma, M., Loha, E., Bogale, A., Teyikie, N., Abuye, C., Stoecker, B. J. (2012). Iodine deficiency in primary school children and knowledge of iodine deficiency and iodized salt among caretakers in Hawassa Town: Southern Ethiopia. Ethiopian J. Health Devel., 26 (1), 30-35.

Gyurjyan, R. H., Lugovska, R., Vevere, P., van der Haar, F. (2006). Newborn thyrotropin screening confirms iodine deficiency in Latvia. Eur. J. Clin. Nutr., 60, 688-690.

Joffe, R., Ozolinšs, G., Šantare, D., Bartkevics, V., Mike, L., Brinkša, I. (2009). Latvijas iedzīvotāju visaptverošais pārtikas patēriņa pētījums, 2007-2009. Rīga.

Jooste, P. L., Upson, N., Charlton, K. E. (2005). Knowledge of iodine nutrition in the South African adult population. Publ. Health Nutr., 8 (4), 382-386.

Khan, G. N., Hussain, I., Soofi, S. B., Rizvi, A., Bhutta, Z. A. (2012). A study on the household use of iodised salt in Sindh and Punjab provinces, Pakistan: Implications for policy makers. J. Pharm. Nutr. Sci., 2, 148-154.

Konrade, I., Kalere, I., Strele, I., Makrecka-Kuka, M., Jekabsone, A., Tetere, E., Veisa, V., Gavars, D., Rezeberga, D., Pīrāgs, V., Lejnieks, A., Dambrova, M. (2015). Iodine deficiency during pregnancy: A national cross-sectional survey in Latvia. Publ. Health Nutr., 18 (16), 2990-2997.

Konrade, I., Neimane, L., Makrecka, M., Strele, I., Liepins, E., Lejnieks, A., Vever, P., Gruntmanis, U., Pīrāgs, V., Dambrova, M. (2014). A cross-sectional survey of urinary iodine status in Latvia. Medicina, $\mathbf{5 0}$ (2), 2014, 124-129.

Konrade, I., Dambrova, M., Makrecka, M., Neimane, L., Strele, I., Liepinsh, E., Lejnieks, A., Vevere, P., Gruntmanis, U., Pirags, V. (2012). Seasonal iodine deficiency in Latvian school children. Thyroid, 22 (10), 1088-1089.

Macías, Y. F., Glasauer, P. (2014). Guidelines for Assessing Nutrition-related Knowledge, Attitudes and Practices. Food and Agriculture Organization of the United Nations, Rome. 180 pp. Available from: http://www.fao.org/docrep/019/i3545e/i3545e.pdf

O’Kane, S. M., Pourshahidi, L. K., Farren, K. M., Mulhern, M. S., Strain, J. J., Yeates, A. J. (2015). Knowledge and awareness of iodine nutrition among women of childbearing age. Irish Section Meeting, 17-19 June 2015, Nutrition at key life stages: New findings, new approaches. Proc. Nutr. Soc., 74 (OCE4), E260.

Selga, G., Sauka, M., Gerasimov, G. (2000). Status of iodine deficiency in Latvia reconsidered: Results of nation-wide survey of 587 school children in the year 2000. IDD Newsletter, 16 (4).

Tulchinsky, T. H. (2010). Micronutrient deficiency conditions: Global health issues. Publ. Health Rev., 32, 243-255.

Zimmermann, M. (2001). Burgerstein's Handbook of Nutrition. Micronutrients in the Prevention and Therapy of Disease. Georg Thieme Verlag. 288 pp. (at pp. 82-84).

\section{PĒTĪJUMS PAR PIEAUGUŠO ZINĀŠANU SAISTĪBĀ AR JODA NOZĪMI UZTURĀ NOVĒRTĒJUMU LATVIJĀ}

FAO norāda, ka ir svarīgi, lai cilvēki saprastu, no kā sastāv veselīgs uzturs, un zinātu, kā visefektīvāk izmantot sev pieejamos resursus. Jods ir nepieciešams zīdītājiem kā obligāts vairogdziedzera struktūras un funkciju elements. Latvijā notikušie pētījumi liecina, ka jaundzimušajiem, skolas vecuma bērniem un grūtniecēm ir tendence uz samazinātu joda daudzumu organismā. Šāda veida pētījumu par vispārējo pieaugušo populāciju nav. Pētījuma mērḳis bija novērtēt pieaugošo populācijas zināšanas par joda nozīmi uzturā. Kopumā tika aptaujāti 199 pieaugušie. Tika ievākti dati par zināšanām par joda atrašanos vidē un pārtikā, joda nozīmi uzturā un iespējamo joda deficītu Latvijā. Pētījuma rezultāti rāda, ka tikai 4,5\% respondentu ekskluzīvi ikdienā lieto jodēto sāli. Ceturtdaḷa respondentu zināja, ka jods ir plaši izplatīts vidē, un vairāk kā trešdaḷa respondentu zināja visas galvenās joda funkcijas organismā. Jodēta sāls un jūras produkti tika nosaukti kā galvenie joda avoti uzturā. Neraugoties uz to, ka jodētā sāls tiek patērēta maz, zināšanas par jodu ir labas un joda deficìts Latvijā varētu būt nesabalansēta uztura nevis zināšanu trūkuma rezultāts. 